\title{
Informacje/Information
}

DOI : $10.14746 /$ pp.2016.21.1.15

\section{Komunikat z posiedzenia Kapituly Ogólnopolskiego Konkursu im. Czesława Mojsiewicza}

Na posiedzeniu V edycji Kapituły Ogólnopolskiego Konkursu im. Profesora Czesława Mojsiewicza na najlepszą książkę o tematyce politologicznej, które odbyło się 22 września 2016 r. na Wydziale Nauk Politycznych i Dziennikarstwa UAM w Poznaniu zebrali się członkowie Kapituły Konkursu w składzie:

- Emilia Mojsiewicz - honorowa przewodnicząca,

- prof. dr hab. Andrzej Stelmach, dziekan WNPiD - przewodniczący,

członkowie:

- prof. dr hab. Roman Bäcker - Uniwersytet Mikołaja Kopernika w Toruniu,

- prof. dr hab. Andrzej Chodubski - Uniwersytet Gdański,

- prof. dr hab. Jan Iwanek - Uniwersytet Śląski,

- prof. dr hab. Edward Olszewski - Uniwersytet Marii Curie-Skłodowskiej,

- prof. dr hab. Teresa Łoś-Nowak - Uniwersytet Wrocławski,

- prof. dr hab. Alicja Stępień-Kuczyńska - Uniwersytet Łódzki,

- prof. dr hab. Arkadiusz Żukowski - Uniwersytet Warmińsko-Mazurski,

- dr Natasza Lubik-Reczek - sekretarz.

Po dokonaniu oceny merytorycznej zgłoszonych publikacji Kapituła Konkursu postanowiła w V edycji Ogólnopolskiego Konkursu im. Profesora Czesława Mojsiewicza na najlepszą książkę o tematyce politologicznej przyznać I nagrodę publikacji Pani Krystyny Leszczyńskiej, Senat Rzeczypospolitej Polskiej w latach 1989-2011, Wydawnictwo Uniwersytetu Marii Curie-Skłodowskiej. Ponadto Kapituła Konkursu postanowiła wyróżnić dwie prace: Pana Marka Rewizorskiego, Agora interesów. G20 i wyłanianie się globalnego zarzqdzania, Wydawnictwo Difin; Pana Rafała Czachora, Postradzieckie reżimy polityczne w perspektywie neopatrymonialnej, Wydawnictwo Fundacji Instytutu Polsko-Rosyjskiego.

Nagroda i wyróżnienia wręczone zostaną podczas corocznej konferencji organizowanej przez WNPiD UAM w Słubicach w dniach 2-3.02.2017 r. 
